\title{
Hubungan Senam Kegel Pada Ibu Hamil Primigravida TM III Terhadap Derajat Robekan Perineum Di Wilayah Puskesmas Pembantu Bandar Kidul Kota Kediri
}

\author{
Shinta Kristianti, Yohanita Putriyana \\ Poltekkes Kemenkes Malang \\ Prodi Kebidanan Kediri Jl.KH.Wakhid Hasyim 64 B Kediri
}

\begin{abstract}
Chiilddbirt injuries often result in the birtht canal, or tearing of the perineum or perineum rupture. Perineum laceration can be caused by maternal parity, estimated fetal weight, and so on becaused the perineum is elastic, but can also be found on the perineum rigid, especially on the first pregnancy (primigravida). Doing Kegel exercises can increase elastisitasion maternal perineum area. Kegel exercises to strengthen pelvic muscles before delivery, and can flex muscle of perineum as delivery baby. The purpose of this study was to determine the relationship of kegel exercises for pregnant women primigravida TM III with the degree of rupture perineum on normal deliveries at Puskesmas Bandar Kidul district of kediri. The design of this study using Analitic Correlation study with crosssectional approach. Population from this study were 19 respondent and Samples were 16 respondents pregnant women primigravida TM III with Consecutive Sampling. Instrument in this study using a cheklist sheet and observation sheets. From the result, the results of most respondents do kegel exercise with frequency $=5 \mathrm{x}$ each day. From the analysis of the data using the Spearman Rank $\mathrm{r}$ count showed $0.12<\mathrm{t}$ table 0.506 means Ho received no relationship kegel exercise with degree of rupture perineum in Puskesmas Bandar Kidul of Kediri. Kegel execises should be done on healing perineal wound.
\end{abstract}

Keywords : Kegel exercises, Primigravida, Degree of rupture perineum

\section{Pendahuluan}

Persalinan primipara dapat menimbulkan perlukaan jalan lahir ataupun pada perineum, Luka persalinan biasanya ringan, tetapi kadang-kadang terjadi juga luka yang luas dan berbahaya. Robekan perineum itu sendiri adalah robekan atau koyaknya jaringan secara paksa yang terletak antara vulva dan anus panjangnya rata-rata $4 \mathrm{~cm}$ (Wiknjosastro, 2007). Trauma jalan lahir perlu mendapatkan perhatian karena dapat menyebabkan disfungsi organ bagian paling luar sampai alat reproduksi vital, sebagai sumber perdarahan yang dapat berakibat fatal, dan sumber atau jalan masuknya infeksi, yang kemudian dapat menyebabkan kematian karena perdarahan atau sepsis (Chapman, 2006). Setiap trauma jalan lahir memerlukan tindakan yang cepat dan tepat karena dapat menjadi sumber perdarahan (Prawiroharjo, 2007).

Jenis trauma jalan lahir salah satunya robekan perineum, yang mengakibatkan robekan tingkat I, II, III, dan IV. Dengan gejala klinis perdarahan ringan, perdarahan sedang, hingga perlukaan dalam, dan apabila robekan terjadi pada sekitar klitoris dan uretra dapat menimbulkan perdarahan hebat dan mungkin sulit untuk diperbaiki (Prawiroharjo, 2007).

Robekan perineum dapat disebabkan oleh paritas ibu, taksiran berat badan janin, dan sebagainya, dikarenakan daerah perineum bersifat elastis, tapi dapat juga ditemukan pada perineum kaku, terutama pada nullipara yang baru mengalami kehamilan pertama (primigravida) (Surinah, 2008).

Di Dunia, berbagai Negara paling sedikit seperempat dari seluruh kematian 
ibu disebabkan oleh perdarahan proporsinya berkisar antara kurang dari 10 $\%$ sampai hampir $60 \%$. Walaupun seorang perempuan bertahan hidup setelah mengalami pendarahan pasca persalinan, namun ia akan menderita akibat kekurangan darah yang berat (anemia berat) dan akan mengalami masalah kesehatan yang berkepanjangan (WHO, 2007).

Menurut Prawiroharjo angka kematian ibu di Indonesia karena perdarahan post partum mempunyai peringkat yang tinggi salah satu penyebab perdarahannya adalah Atonia Uteri atau tidak adanya kontraksi pada uterus, dan robekan perineum menjadi penyebab perdarahan postpartum kedua. (Prawiroharjo, 2007). Berdasarkan data yang diperoleh dari Dinas Kesehatan Propinsi Jawa Timur, selama tahun 2011 tercatat sebanyak $627 \mathrm{ibu}$ yang meninggal dunia di Jawa Timur. Penyebab utama kematian ibu di Jatim adalah perdarahan saat persalinan dan tekanan darah tinggi saat hamil (preeklamsia). (Dinkes Jatim, 2011). Jumlah AKI yang disebabkan oleh perdarahan di Propinsi Jawa Timur, selama 2009 sebanyak 260 ribu ibu meninggal setiap 10.000 kelahiran per tahun. Angka ini menurun dibanding 2007, yakni 320 ribu ibu meniggal setiap 10.000 kelahiran per tahun. Tahun 2015, ditarget AKI turun sampai 112 ribu (Jatimprov, 2010). Sementara berdasarkan hasil dari studi pendahuluan untuk wilayah Kota Kediri pada tahun 2012 angka kejadian perdarahan persalinan didapatkan sebanyak 10 dari 3365 persalinan, atau sekitar 0,297\%.

Bahaya dan komplikasi robekan perineum antara lain perdarahan, infeksi, dan disparenia (nyeri selama hubungan seksual). Perdarahan pada robekan perineum dapat menjadi hebat khususnya pada robekan derajat III dan IV atau jika robekan meluas kesamping atau naik ke vulva mengenai klitoris. Karena letak perineum berdekatan dengan anus, laserasi perineum dapat dengan mudah terkontaminasi feses. Infeksi juga dapat menjadi sebab luka tidak segera menyatu sehingga timbul jaringan parut. Jaringan parut yang terbentuk sesudah laserasi perineum inilah yang nantinya dapat menyebabkan nyeri selama berhubungan seksual (Seller, 2008).

Penelitian Ruliati (2010) yang berjudul pengaruh pijat perineum pada kehamilan terhadap kejadian ruptur perineum pada persalinan di Bidan Praktek Swasta BPS Siswati dan BPS Siti Zulaikah Jombang, mengatakan pada kelompok yang diberikan intevensi pijat perineum : primigravida tidak mengalami ruptur sebanyak $44,4 \%$, ruptur derajat I $55,6 \%$, sedangkan pada multigravida tidak mengalami ruptur perineum sebanyak $55,6 \%$, ruptur derajat I sebanyak $44,4 \%$. Pada kelompok kontrol : primigravida yang tidak mengalami ruptur perineum sebanyak $22,2 \%$, ruptur perineum derajat I sebanyak 22,2\%, dan ruptur perineum derajat II sebanyak 55,6\%. Sedangkan untuk multigravida yang tidak mengalami ruptur perineum sebanyak 11,1\%, 33,3\% mengalami ruptur perineum derajat $\mathrm{I}$, dan $55,6 \%$ dengan ruptur perineum derajat II.

Ada beberapa cara yang dapat digunakan untuk mencegah terjadinya robekan perineum karena persalinan normal, diantaranya adalah mengajarkan ibu untuk sering melakukan senam Kegel, serta menganjurkan ibu untuk memilih posisi yang nyaman, meneran saat ada his, tidak mengangkat bokong saat meneran, bagi petugas kesehatan tidak melakukan dorongan pada fundus untuk membantu kelahiran bayi, serta melindungi perineum saat kepala mulai tampak 5-6 cm di depan vulva dengan satu tangan untuk menahan belakang kepala bayi agar tetap fleksi pada saat keluar (JNPK-KR, 2007).

Senam Kegel adalah senam untuk menguatkan otot dasar panggul menjelang persalinan, tujuannya untuk menguatkan otot-otot dasar panggul, membantu mencegah masalah inkontinensia urine, serta dapat melenturkan jaringan perineum 
sebagai jalan lahir bayi. Sehingga seluruh ibu harus dimotivasi untuk menggerakan otot dasar panggul sedikit-sedikit dan sesering mungkin, perlahan dan cepat pada masa mendekati persalinan. Prosedur senam Kegel dapat diingat dan dilakukan bersama aktifitas yang berkaitan dengan kegiatan ibu sehari hari. Seperti saat ibu duduk di kamar mandi setelah berkemih dan ini adalah posisi relaks untuk mengkontraksi otot tersebut, serta pada saat ibu ingin tidur dan dalam keadaan apapun. Melakukan senam Kegel secara teratur dapat membantu melenturkan jaringan perineum ibu menyambut persalinan (Proverawati, 2012).

\section{Metode Penelitian}

$\begin{array}{ccc}\text { Penelitian } & \text { ini } & \text { menggunakan } \\ \text { rancangan } & \text { Analitik } & \text { Corelation. }\end{array}$ Pendekatan yang digunakan Cross Sectional, metode Analitik Corelation ini digunakan untuk mengukur korelasi antara senam kegel yang dilakukan pada ibu hamil primigravida TM III dengan robekan perineum pada persalinan normal. Populasi dalam penelitian ini adalah semua ibu hamil primigravida TM III di Wilayah Puskesmas Pembantu Bandar Kidul Kota Kediri yang memenuhi kriteria inklusi dalam penelitian. Jumlah populasi dalam penelitian ini adalah 20 orang ibu hamil primigravida TM III, sedangkan sampelnya adalah sebagian ibu hamil primigravida TM III di Wilayah Puskesmas Pembantu Bandar Kidul Kota Kediri yang memenuhi kriteria inklusi dalam penelitian. Jumlah sampel dalam penelitian ini sejumlah 10 orang yang diambil dengan consecutive sampling .

Cara yang akan dilakukan oleh peneliti yaitu pengambilan sampel dengan meneliti responden ibu hamil yang sesuai dengan kriteria inklusi di Wilayah Puskesmas Pembantu Bandar Kidul Kota Kediri, dipantau dalam beberapa kurun waktu tertentu hingga pada saat persalinan dilakukan observasi.

Pada penelitian ini instrumen yang digunakan untuk mengetahui senam Kegel yang dilakukan oleh ibu adalah lembar cheklis sedangkan untuk kejadian robekan perineum menggunakan lembar observasi pada saat persalinan. Analisa hubungan antara senam Kegel dengan derajat robekan perineum, peneliti menggunakan rumus Spearman Rank.

\section{Hasil Penelitian \\ Frekuensi Senam Kegel}

Tabel 1. Distribusi Frekuensi Senam Kegel

\begin{tabular}{ccc}
\hline $\begin{array}{c}\text { Frekuensi } \\
\text { Senam Kegel }\end{array}$ & Frekuensi & $\%$ \\
\hline $1 . \quad<5 \mathrm{x}$ & 5 & 31,25 \\
$2 . \quad=5 \mathrm{x}$ & 7 & 43,75 \\
$3 . \quad>5 \mathrm{x}$ & 4 & 25,00 \\
\hline Jumlah & 16 & 100,00 \\
\hline
\end{tabular}

Berdasarkan tabel 1 dapat diketahui hampir setengahnya responden telah melaksanakan senam Kegel $=5 \mathrm{x}$ setiap harinya yaitu sebesar 7 responden $(43,75 \%)$ dari total 16 responden.

\section{Frekuensi Derajat Robekan Perineum}

Tabel2. Distribusi Frekuensi Derajat Robekan Perineum

\begin{tabular}{ccc}
\hline $\begin{array}{c}\text { Derajat Robekan } \\
\text { Perineum }\end{array}$ & Frekuensi & $\%$ \\
\hline Derajat 0 & 1 & 6,25 \\
Derajat 1 & 6 & 37,50 \\
Derajat 2 & 9 & 2,25 \\
\hline Jumlah & 16 & 100,00 \\
\hline
\end{tabular}

Berdasarkan tabel 2 dapat diketahui sebagian besar responden mengalami robekan perineum derajat 2 pada saat persalinan yaitu sebesar 9 responden $(52,25 \%)$ dari total 16 responden.

Hubungan Senam Kegel Pada Ibu Hamil Primigravida Trimester III Terhadap Derajat Robekan Perineum

Tabel 3. Hubungan Senam Kegel Pada Ibu Hamil Primigravida Trimester III Terhadap Derajat Robekan Perineum

\begin{tabular}{lccccc}
\hline & Frekuensi & \multicolumn{3}{c}{ Derajat Robekan Perineum } \\
N & Senam & \multicolumn{4}{c}{} \\
\cline { 3 - 5 } o & Kegel & Derajat & Derajat & Derajat & $\Sigma$ \\
& & 0 & 1 & 2 & \\
1. & $<5 \mathrm{x}$ & 0 & 2 & 3 & 5 \\
2. & $=5 \mathrm{x}$ & 1 & 2 & 4 & 7 \\
3. & $>5 \mathrm{x}$ & 0 & 2 & 2 & 4 \\
JUMLAH & 1 & 6 & 9 & 16 \\
\hline
\end{tabular}


Berdasarkan tabel 3 diketahui sebagian besar responden yang memiliki frekuensi senam Kegel $=5 \mathrm{x}$ dan mengalami robekan perineum derajat 2 sebanyak 4 responden $(57,1 \%)$ dan hampir setengah responden yang memiliki frekuensi senam Kegel $<5 \mathrm{x}$ dan mengalami robekan perineum derajat 2 sebanyak 3 responden $(60,0 \%)$. Hal tersebut menunjukan bahwa semakin sering melakukan senam Kegel belum tentu dapat meminimalkan terjadinya robekan perineum dengan derajat yang rendah.

Guna membuktikan kecenderungan hubungan senam Kegel terhadap derajat robekan perineum maka dilakukan analisis Korelasi Spearman rank. Hasil analisa sebagai berikut:

Tabel 4. Uji Korelasi Spearman Rank Hubungan Senam Kegel dengan Derajat Robekan Perineum

\begin{tabular}{ccc}
\hline Variabel & r tabel & $r$ \\
\hline Senam Kegel - Derajat & 0,506 & 0,12 \\
Robekan Perineum & & \\
$\mathrm{N}=16$ & & \\
$\alpha=0,05$ & & \\
\hline
\end{tabular}

Berdasarkan hasil penghitungan $\rho$ hitung didapatkan hasil 0,12 untuk hasil analisa hubungan senam Kegel dengan derajat robekan perineum. Dari tabel terlihat bahwa untuk $n=16$, pada taraf kesalahan 5\% diperoleh harga 0,506 dan Hasil rho hitung ternyata lebih kecil dari rho tabel untuk taraf kesalahan 5\%. Berdasarkan hal tersebut menunjukan tidak terdapat kesesuaian yang nyata/signifikan antara frekuensi senam Kegel dengan derajat robekan perineum. Dari tabel 5.5 diketahui tidak ada hubungan senam Kegel dengan derajat robekan perineum ibu di Puskesmas Bandar Kidul Kota Kediri ( $\rho=0,12<$ 0,506 maka Ha ditolak).

\section{Pembahasan}

Puskemas Pembatu Bandar Kidul Kota Kediri adalah Puskesmas Pembatu Wilayah Campurejo Kota Kediri, pada Puskesmas ini terdapat data Ibu hamil primigravida dengan kunjungan K4 terbanyak di Wilayah Kota Kediri, dan merupakan sasaran dari peneliti sehingga peneliti memilih Puskesmas Pembantu Bandar Kidul Kota Kediri sebagai tempat penelitian. Dalam penelitian ini populasi berjumlah 19 responden, yaitu seluruh Ibu Hamil Primigravida TM III Di Wilayah Puskesmas Bandar Kidul Kota Kediri yang termasuk dalam kriteria inklusi penelitian (consecutive sampling). Namun dalam proses penelitian terdapat 3 responden masuk dalam kriteria eksklusi. 2 responden dilakukan episiotomi dan 1 responden dilakukan tindakan (SC).

\section{Karakteristik Frekuensi Senam Kegel Ibu Hamil Primigravida TM III}

Pada penelitian yang telah dilakukan di dapatkan hasil diketahui hampir setengahnya responden telah melaksanakan senam Kegel $=5 \mathrm{x}$ setiap harinya yaitu sebesar 7 responden $(43,75 \%)$ dari total 16 responden. Hal ini dikarenakan ibu terkadang lupa untuk melakukan anjuran dari peneliti.

Bila senam Kegel dilakukan secara teratur maka dapat dirasakan manfaatnya. Untuk hasil terbaik, senam Kegel perlu dilakukan secara konstan setiap hari. Hasilnya tidak akan didapat dalam waktu sehari. Kebanyakan orang akan merasakan perubahan setelah 3 minggu dengan berlatih beberapa menit setiap hari. Bagi wanita sebaiknya senam Kegel ini dilakukan sepanjang hidup, tidak hanya pada saat hamil saja, bila rajin melakukan senam Kegel sejak muda, maka ketika tua otot panggul akan tetap kuat sehingga terhindar dari mengompol, sulit menahan kencing dan masalah-masalah lainnya yang sering dialami oleh para lansia (Widianti \& Proverawati, 2010).

Keelastisitasan otot-otot perineum yang telah dilatih oleh senam Kegel saat mendekati persalinan dapat meminimalkan terjadinya robekan perineum pada saat persalinan, minimnya robekan yang terjadi pada saat persalinan 
dapat turut meminimalkan juga resiko infeksi penyembuhan dari luka perineum.

Hal ini juga sependapat dengan penelitian yang dilakukan oleh Novita (2012) dari Kelompok yang diberikan intervensi senam Kegel sebanyak 7 responden, didapatkan 5 responden $(71,4 \%)$ mengalami penyembuhan luka perineum lebih awal di banding 2 responden lainnya. Sedangkan pada kelompok kontrol sebanyak 7 responden, yang tidak diberikan intervensi senam Kegel $2(28,57 \%)$ diantaranya mengalami penyembuhan luka perineum lebih awal. Hal ini menunjukan bahwa senam Kegel bukan merupakan faktor utama dalam penyembuhan luka perineum karena peneliti tidak memberikan lembar pemantauan yang diberikan untuk mencatat hasil melakukan senam Kegel selama dirumah (Novita,2012).

Penanganan yang dianjurkan terhadap keadaan diatas adalah dengan memahami seutuhnya manfaat besar dari senam Kegel bagi wanita. Disaat seluruh wanita paham tentang manfaat dari senam kegel (terutama responden) maka wanita akan melakukan senam Kegel dengan senang hati, sesering mungkin, kapanpun dan dimanapun ia berada, sehingga wanita tersebut dapat dengan mudah merasakan berbagai macam manfaat dari senam Kegel.

\section{Derajat Robekan Perineum Pada Ibu Bersalin Normal.}

Pada penelitian yang telah dilakukan diketahui sebagian besar responden mengalami robekan perineum derajat 2 pada saat persalinan yaitu sebesar 9 responden $(52,25 \%)$ dari total 16 responden. Hal ini mungkin dikarenakan responden hanya memiliki frekuensi melakukan senam Kegel $=5 \mathrm{x}$ setiap harinya, berat badan lahir bayi, serta keadaan responden yang seluruhnya nulipara. Hal ini sangat memungkinkan terjadinya derajat robekan perineum derajat 2, nulipara memiliki otot-otot perineum yang kaku dibanding ibu bersalin primi/multipara.

Hal ini sependapat dengan teori yang dikemukakan oleh Sarwono (2009) mengatakan bahwa salah satu faktor resiko terjadinya robekan perineum adalah Primigravida. Serta didukung juga dengan teori yang mengatakan bahwa paritas sangat berpengaruh dengan terjadinya robekan perineum pada saat proses persalinan berlangsung, hal ini dikarenakan daerah perineum bersifat elastis, tapi dapat juga ditemukan perineum yang kaku, terutama pada nullipara yang baru mengalami kehamilan pertama (primigravida) (Surinah, 2008).

Berdasarkan jurnal yang didapatkan dari penelitian yang dilakukan di BPS Yohana daerah Bandarharjo Semarang pada April 2012, hasil pemantaun persalinan yang menggunakan partograf menunjukan bahwa dari $60 \%$ ibu bersalin yang mengalami laserasi perineum dan $67 \%$ diantaranya adalah primipara. Setelah dilakukan wawancara dengan ketiga ibu bersalin yang mengalami laserasi perineum ternyata selama hamil tidak melakukan senam Kegel. Observasi menunjukan bahwa laserasi perineum mayoritas dialami oleh primipara yang tidak melakukan senam Kegel (Yanti,2012).

Pada ibu bersalin nulipara masih memiliki keadaan perineum yang utuh dibanding ibu bersalin primi/multipara, karena pada ibu bersalin nulipara otot-otot perineum belum mengalami trauma (persalinan). Dibanding dengan ibu bersalin primi/multipara yang sudah mengalami trauma (persalinan) dengan jumlah yang berbeda. Oleh sebab itu, dapat ditarik kesimpulan bahwa pada seorang nulipara resiko terjadinya robekan perineum semakin tinggi dibanding dengan seorang primi/multipara yang mengalami robekan perineum pada saat berlangsungnya proses persalinan.

Penanganan dari keadaan tersebut diatas adalah dengan menganjurkan ibu hamil untuk sesering mungkin melakukan 
senam Kegel saat mendekati proses persalinan, karena senam Kegel dapat meningkatkan keelastisitasan otot-otot perineum ibu terlebih pada seorang nulipara. Serta didukung dengan peran penolong persalinan dalam hal ini bidan untuk mengantisipasi dan menangani komplikasi yang mungkin terjadi pada ibu dan janin. Proses keberhasilan berlangsungnya persalinan tergantung dari kemampuan skill dan kesiapan penolong dalam menghadapi persalinan (Bobak,2005).

\section{Hubungan Senam Kegel Pada Ibu Hamil Primigravida TM III Terhadap Derajat Robekan Perineum.}

Hasil penelitian diketahui bahwa sebagian besar responden yang memiliki frekuensi senam Kegel $=5 \mathrm{x}$ dan mengalami robekan perineum derajat 2 sebanyak 4 responden $(57,1 \%)$ dan hampir setengah responden yang memiliki frekuensi senam Kegel $<5 \mathrm{x}$ dan mengalami robekan perineum derajat 2 sebanyak 3 responden $(60,0 \%)$. Hal tersebut menunjukan bahwa senam Kegel bukan merupakan faktor utama dalam meminimalkan terjadinya robekan perineum. Setelah dilakukan analisis Korelasi Spearman rank didapatkan hasil analisis sebagai berikut: diketahui tidak ada hubungan senam Kegel dengan derajat robekan perineum ibu di Puskesmas Bandar Kidul Kota Kediri ( $\rho=$ $0,12<0,506$ maka Ha ditolak).

Hal ini tidak sepedapat dengan teori mengatakan manfaat dari senam Kegel salah satunya dapat memudahkan wanita melahiran bayi tanpa banyak merobek jalan lahir (tanpa atau sedikit merobek jalan lahir) (Proverawati,2010).

Penelitian Ruliati (2010) yang berjudul pengaruh pijat perineum pada kehamilan terhadap kejadian ruptur perineum pada persalinan di Bidan Praktek Swasta BPS Siswati dan BPS Siti Zulaikah Jombang, mengatakan pada kelompok yang diberikan intevensi pijat perineum: primigravida tidak mengalami ruptur sebanyak $44,4 \%$, ruptur derajat I $55,6 \%$, sedangkan pada multigravida tidak mengalami ruptur perineum sebanyak $55,6 \%$, ruptur derajat I sebanyak $44,4 \%$. Pada kelompok kontrol: primigravida yang tidak mengalami ruptur perineum sebanyak $22,2 \%$, ruptur perineum derajat I sebanyak 22,2\%, dan ruptur perineum derajat II sebanyak 55,6\%. Sedangkan untuk multigravida yang tidak mengalami ruptur perineum sebanyak $11,1 \%, 33,3 \%$ mengalami ruptur perineum derajat I, dan $55,6 \%$ dengan ruptur perineum derajat II (Yanti,2012).

Tidak terdapatnya hubungan senam Kegel dengan derajat robekan perineum juga tidak dapat dipungkiri. Hal ini terjadi karena terjadinya robekan perineum juga dipengaruhi oleh beberapa faktor, faktor ibu dan janin. Diantaranya paritas ibu, ukuran besar janin, serta kemahiran penolong dalam memimpin persalinan.

Dalam penelitian ini responden yang telah melakukan senam Kegel dengan teratur namun mengalami robekan perineum derajat 2 mungkin dikarenakan berat badan lahir bayi dan kemahiran penolong. Hal ini sesuai dengan teori yang dikemukakan oleh Prawiroharjo (2009) yang mengatakan robekan perineum dapat dipengaruhi dari faktor janin yaitu dimana keadaan kepala janin yang besar, janin dengan presentasi defleksi, janin dengan letak sungsang, serta janin makrosomia.

Sementara untuk kemahiran penolong sesuai dengan teori yang tertulis dalam Buku Acuan Asuhan Persalinan Normal (2008) kerjasama dengan ibu dan penggunaan manual yang tepat dapat mengatur kecepatan lahirnya bayi dan mencegah terjadinya laserasi. Pengendalian kecepatan dan pengaturan diameter kepala saat melalui introitus dan perineum dapat mengurangi kemungkinan terjadinya robekan perineum. Bimbing ibu untuk meneran dan beristirahat atau bernapas dengan cepat pada waktunya. Saat kepala membuka vulva $(5-6 \mathrm{~cm})$, letakan kain bersih dan kering yang dilipat $1 / 3$ 
bagiannya dibawah bokong ibu (untuk mengeringkan bayi segera setelah lahir). Lindungi perineum dengan satu tangan (dibawah kain bersih dan kering), ibu jari pada salah satu sisi perineum dan 4 jari tangan pada sisi yang lain pada belakang kepala bayi. Tahan belakang kepala bayi agar posisi kepala tetap fleksi pada saat keluar secara bertahap melewati introitus dan perineum. Melindungi perineum dan mengendalikan keluarnya kepala bayi secara bertahap dan hati-hati dapat mengurangi regangan berlebihan (robekan) pada vagina dan perineum.

Penanganan yang dapat digunakan untuk mengurangi terjadinya robekan perineum pada saat persalinan spontan yaitu dengan cara senantiasa melakukan senam Kegel dari masih muda hingga selanjutnya dengan sesering mungkin dan konstan, serta menjaga masa kehamilan dengan cermat dan sehat, selalu memeriksakan kehamilan pada pelayan kesehatan yang terjangkau guna mendeteksi keadaan serta kesejahteraan janin di dalam kandungan, serta mengatur asupan nutrisi dengan pola diit yang seimbang.

\section{KESIMPULAN}

Kesimpulan penelitian ini yaitu

1. Hampir setengah dari responden telah melaksanakan senam kegel dengan frekuensi $=5 \mathrm{x}$ setiap harinya.

2. Sebagian besar responden mengalami robekan perineum derajat 2 pada saat persalinan.

3. Tidak ada hubungan dilakukannya senam Kegel pada ibu hamil primigravida TM III terhadap derajat robekan perineum pada persalinan normal, $(\rho=0,12<0,506$ maka Ha ditolak).

\section{SARAN}

\section{Bagi Peneliti Selanjutnya}

Hasil penelitian ini dapat digunakan sebagai dasar informasi tentang manfaat senam Kegel untuk wanita pada umumnya dan responden (ibu hamil) pada khususnya, mengingat manfaat senam Kegel sangat beragam seperti menghindari ngompol pada lansia, meningkatkan keelastisitasan otot-otot perineum pada ibu hamil dan ibu nifas, serta lebih mudah mencapai orgasme bagi wanita, dll. Apabila dilakukan sesuai dengan prosedur yang telah ditentukan.

\section{Bagi Responden}

Diharapkan bagi ibu hamil TM III setiap harinya melaksanakan senam Kegel sesuai prosedur untuk membantu meningkatkan keelastisitasan otot-otot perineum yang dapat mengurangi derajat robekan perineum pada saat persalinan.

\section{Daftar Pustaka}

Abdurahman, M, dkk. 2011. Dasar-dasar Metode Statistika Untuk Penelitian. Bandung : Pustaka Setia.

Bobak, I, dkk. 2005. Buku Ajar Keperawatan Maternitas. Jakarta : EGC.

Brock, Katie. 2007. Nutrisi, Medikasi, dan Senam Kehamilan. Jakarta : Prestasi Pustakaraya.

Chapman, V. 2006. Asuhan Persalinan dan Kelahiran. Jakarta : EGC.

Hidayat, A. A. A. 2005. Metode Penelitian Kebidanan \& Teknik Analisis Data Jakarta : Salemba Medika.

Jones, Ilewellyn. 2002. Dasar-dasar Obstetri dan Ginekologi Edisi 6. Jakarta : Hipokrates.

Kusmiyati, Y, dkk. 2009. Perawatan Ibu Hamil. Yogyakarta : Fitramaya.

Liu, D. 2008. Manual Persalinan (Labour Ward Manual) Edisi 3. Jakarta : EGC.

Maimunah, S. 2005. Kamus Kebidanan. Jakarta : EGC.

Manuaba, C, dkk. 2008. Gawat Darurat Obstetri-Ginekologi \& ObstetriGinekologi Sosial untuk Profesi Bidan. Jakarta : EGC. 
Notoatmodjo, S. 2002. Metodologi Penelitian Kesehatan. Jakarta : Rineka Cipta.

Prawiroharjo, S. 2005. Buku Acuan Nasional Pelayanan Kesehatan Maternal dan Neonatal Edisi 1. Jakarta : Yayasan Bina Pustaka Sarwono Prawiroharjo. . 2007. Ilmu Kebidanan

Edisi 3. Jakarta : Yayasan Bina Pustaka Sarwono Prawiroharjo.

Proverawati, 2010. Senam Kesehatan Aplikasi Senam Untuk Kesehatan. Yogyakarta : Muha Medika.

Pujiastuti, S, dkk. 2003. Fisioterapi Untuk Lansia. Jakarta : EGC.

Ruliati, 2010. Pengaruh Pijat Perineum Pada Kehamilan terhadap Kejadian Ruptur Perineum pada Persalinan di BPS Jombang. Malang : UMM. Karya Tulis Ilmiah.

Sastrawinata. 2005. Obstetri Ginekologi Universitas Padjajaran Bandung. Bandung : Elstra Offset.

Saifuddin, A. 2007. Ilmu Kandungan Sarwono Prawirohardjo. Jakarta : YBPSP.

Setiawan, A. 2010. Metodologi Penelitian Kebidanan DIII, DIV, S1, S2 Edisi 1. Yogyakarta : Muha Medika.

Stoppard, W. 2005. Panduan Mempersiapkan Kehamilan \& Kelahiran. Yogyakarta : Pustaka Pelajar.

Sumarah. 2008. Asuhan Persalinan Normal \& Inisiasi Menyusui Dini. Jakarta : JNPK - KR. 2009. Perawatan Ibu Bersalin (Asuhan Kebidanan Pada Ibu Bersalin). Yogyakarta : Fitramaya.

Sugiyono, 2010. Statistika Untuk Penelitian. Bandung : Alfabeta.

Suririnah, 2008. Buku Pintar Kehamilan \& Persalinan (Panduan Bagi Calon Ibu Untuk Menjalani Kehamilan yang Sehat \& Menyenangkan). Jakarta : Gramedia.

Suseno T, 2009. Kamus Kebidanan. Yogyakarta : Cipta Pustaka Yogyakarta.
Ujiningtyas, S. 2009. Asuhan Keperawatan Persalinan Normal. Jakarta : Salemba Medika.Walsh, L. 2007. Buku Ajar Kebidanan Komunitas. Jakarta : EGC.

Verralls, S. 2003 : Anatomi \& Fisiologi Terapan dalam Kebidanan. Jakarta : EGC.

Wiknjosastro, H. 2002. Buku Panduan Praktis Pelayanan Kesehatan Maternal dan Neonatal. Jakarta : Tridasa Printer.

Yanti, 2012. Jpttunumus-gdlherfinaoctt/2012/senamkegel.html.(di akses 15 Januari 2013). 